\title{
In-vitro alpha amylase inhibitory activity of the leaf extracts of Adenanthera pavonina
}

\author{
M. Nirmali Wickramaratne ${ }^{1 *}$, J. C. Punchihewa ${ }^{2}$ and D. B. M. Wickramaratne ${ }^{3}$
}

\begin{abstract}
Background: Diabetes has caused a major burden to the health sector in the developing countries and has shown an increasing trend among the urban population. It is estimated that most patients are with type II diabetes which could be easily treated with dietary changes, exercise, and medication. Sri Lanka carries a long history ayurvedic medicine where it uses the plant for treating many diseases. Therefore it is important to screen medicinal plants scientifically so they could be used safely and effectively in the traditional medical system and also be used for further investigations.

Adenanthera pavonina is a plant used in the Ayurvedic medical system in Sri Lanka for treating many diseases including diabetics. We evaluated the anti-diabetic properties and the antioxidant properties of Adenanthera pavonina leaves.

Methods: The methanol extract of the leaves was sequentially extracted with petroleum ether and thereafter was partitioned between EtOAc, and water. The a-amylase inhibition assay was performed using the 3,5- dinitrosalicylic acid method. The antioxidant activities were measured using the DPPH free radical scavenging activity and the total phenolic content using Folin-Ciocalteu's reagent. The cytotoxicity of the extract was evaluated using the Brine shrimp bioassay.

Results: The $\mathrm{IC}_{50}$ values of a amylase inhibitory activity of $\mathrm{MeOH}$, EtOAc, petroleum ether, and water were $16.16 \pm$ $2.23,59.93 \pm 0.25,145.49 \pm 4.86$ and $214.85 \pm 9.72 \mu \mathrm{g} / \mathrm{ml}$ respectively and was similar to that of Acarbose $(18.63 \pm 1$. $21(\mathrm{\mu g} / \mathrm{ml})$. Antioxidant activities were also determined and the EtOAc fraction showed the highest total phenolic content (34. $62 \pm 1.14 \mathrm{mg} / \mathrm{g}$ extract) and the highest DPPH scavenging activity with an IC 50 of $249.92 \pm 3.35 \mu \mathrm{g} / \mathrm{ml}$.

Conclusion: The leaf extracts of Adenanthera pavonina exhibit remarkable a-amylase inhibitory activity in the crude methanolic extract. Hence leaves of Adenanthera pavonina has a potential to be used as a regular green vegetable and also be investigated further in isolating pure compounds with anti-diabetic activity.
\end{abstract}

\section{Background}

It is estimated that the global prevalence of diabetes is increasing each year causing a major burden to the health sector, especially in the developing countries. It is estimated that the prevalence of diabetes is high among the urban population [1] where $90 \%$ is accounted to be type II diabetic [2]. Patients with type II diabetes can be easily treated with dietary changes, exercise, and medication. The complications arising with diabetes are closely related to the production of free radicals enhancing the oxidative

\footnotetext{
* Correspondence: meritanirmali@gmail.com

'Department of Physical Sciences and Technology, Faculty of Applied Sciences, Sabaragamuwa University of Sri Lanka, Belihuloya, Sri Lanka Full list of author information is available at the end of the article
}

stress [3]. Hence the use of antioxidants has been effective in reducing the severity of diabetic complications [4].

The traditional medical systems in countries like China, India, North Africa and Sri Lanka use decoctions or fresh mixtures of juices made from medicinal plants in treating most diseases like cancer, arthritis, diabetics etc. Adenanthera pavonina (Madatiya -Sinhala, Circassian bean-English) belonging to the family Fabaceae; used in traditional herbal medicine for a variety of diseases including diabetes, lipid disorders, diarrhea, hemorrhage, and as an anti-inflammatory agent [5]. Phytochemical investigations of the plant have identified many compounds which are steroids, glycosides, alkaloids, saponins, polysaccharides, fatty acids and various amino acids $[5,6]$ with no claims of any of the above compounds to be active as an antidiabetic 
compound. Studies performed on the seed and leaf extracts on rat models have shown to possess hypoglycemic and antihyperglycemic activity [7]. The seeds are reported to be toxic, but some consume the roasted seed while the suburban population in countries like India and Sri Lanka, consumes the tender leaves as a green vegetable in their regular diet (http://www.worldagroforestry.org/ treedb/AFTPDFS/Adenanthera_pavonina.PDF).

It is important to evaluate the antidiabetic activity of the leaves quantitatively which would allow the use of Adenanthera pavonina (A. pavonina) leaves in a more efficient and effective manner in treating diabetics. Therefore the present investigation was carried out to evaluate the invitro $\alpha$ - amylase inhibitory activity and the antioxidant activity of the leaf extracts of $A$. pavonina.

\section{Methods}

All chemicals used were of analytical reagent grade. 1,1-Diphenyl-2-picrylhydrazyl radical (DPPH), 3,5 dinitro salicylic acid (DNSA), Gallic acid and $\alpha$-amylase from Aspergillus oryzae purchased from (Sigma USA). Dimethylsulfoxide (DMSO) was purchased SigmaAldrich. UV-visible spectrophotometer (Thermo Fisher Scientific G10S).

Collection of plant materials: Fresh leaves of A. pavonina were collected from Peradeniya and their authenticity was confirmed by The National Herbarium, Royal Botanic Gardens, Peradeniya, Sri Lanka.

\section{Plant extract}

Air-dried, powdered leaves (200 g) of A. pavonina were extracted with methanol $(\mathrm{MeOH})$ at room temperature for $2 \times 24$ h using $1500 \mathrm{ml}$ of $\mathrm{MeOH}$ for each extraction. The combined $\mathrm{MeOH}$ extracts were concentrated under vacuum at $40{ }^{\circ} \mathrm{C}$ to $1 \mathrm{~L}$ and were partitioned into petroleum ether $(2 \times 500 \mathrm{ml})$. The combined petroleum ether fraction was filtered and dried over anhydrous $\mathrm{Na}_{2} \mathrm{SO}_{4}$ and was evaporated under vacuum to dryness. The dried petroleum ether extract was refrigerated in a tightly closed container until use. The remaining methanol fraction was evaporated under vacuum to dryness and residue was partitioned between ethyl acetate (EtOAc, $1 \mathrm{~L}$ ) and water $(1 \mathrm{~L})$. The ethyl acetate extract was dried over anhydrous $\mathrm{Na}_{2} \mathrm{SO}_{4}$ and was evaporated under vacuum to dryness and refrigerated until further use. The aqueous fraction was frozen and freeze-dried and the residue was stored in the refrigerator until further use.

\section{In vitro a-amylase inhibitory studies}

The $\alpha$-amylase inhibition assay was performed using the 3,5-dinitrosalicylic acid (DNSA) method [8]. The leaf extract of $A$. pavonina was dissolved in minimum amount of $10 \%$ DMSO and was further dissolved in buffer $\left(\left(\mathrm{Na}_{2} \mathrm{HPO}_{4} / \mathrm{NaH}_{2} \mathrm{PO}_{4}(0.02 \mathrm{M}), \mathrm{NaCl}(0.006 \mathrm{M})\right.\right.$ at $\left.\mathrm{pH} 6.9\right)$ to give concentrations ranging from 10 to $1000 \mu \mathrm{g} / \mathrm{ml}$. A volume of $200 \mu \mathrm{l}$ of $\alpha$-amylase solution ( 2 units $/ \mathrm{ml}$ ) was mixed with $200 \mu \mathrm{l}$ of the extract and was incubated for $10 \mathrm{~min}$ at $30{ }^{\circ} \mathrm{C}$. Thereafter $200 \mu \mathrm{l}$ of the starch solution $(1 \%$ in water $(\mathrm{w} / \mathrm{v}))$ was added to each tube and incubated for $3 \mathrm{~min}$. The reaction was terminated by the addition of $200 \mu \mathrm{l}$ DNSA reagent (12 $\mathrm{g}$ of sodium potassium tartrate tetrahydrate in $8.0 \mathrm{~mL}$ of $2 \mathrm{M} \mathrm{NaOH}$ and $20 \mathrm{~mL}$ of $96 \mathrm{mM}$ of 3,5-dinitrosalicylic acid solution) and was boiled for $10 \mathrm{~min}$ in a water bath at $85-90{ }^{\circ} \mathrm{C}$. The mixture was cooled to ambient temperature and was diluted with $5 \mathrm{ml}$ of distilled water, and the absorbance was measured at $540 \mathrm{~nm}$ using a UV-Visible spectrophotometer. The blank with $100 \%$ enzyme activity was prepared by replacing the plant extract with $200 \mu \mathrm{l}$ of buffer. A blank reaction was similarly prepared using the plant extract at each concentration in the absence of the enzyme solution. A positive control sample was prepared using Acarbose $(100 \mu \mathrm{g} / \mathrm{ml}-2 \mu \mathrm{g} / \mathrm{ml})$ and the reaction was performed similarly to the reaction with plant extract as mentioned above. The $\alpha$-amylase inhibitory activity was expressed as percent inhibition and was calculated using the equation given below: The $\% \alpha$-amylase inhibition was plotted against the extract concentration and the $\mathrm{IC}_{50}$ values were obtained from the graph.

$$
\% \alpha \text { amylase inhibition }=100 \times \frac{\mathrm{Abs}_{100 \% \text { control }}-\mathrm{Abs}_{\text {Sample }}}{\mathrm{Abs}_{100 \% \text { Control }}}
$$

\section{Antioxidant activity of $A$. pavonina leaf extract $D P P H$ radical scavenging activity}

Free radical scavenging activity of $A$. pavonina leaf extract was measured using the DPPH assay as in Gulluce et al., [9] with slight modifications. The plant extract was dissolved in methanol and prepared samples with different concentrations ranging from 50 to $1000 \mu \mathrm{g} / \mathrm{ml}$. A methanolic solution $(0.1 \mathrm{M})$ of DPPH was freshly prepared and kept in dark at $4{ }^{\circ} \mathrm{C}$ until use. A volume of $1 \mathrm{ml}$ of the extract was added into $1 \mathrm{ml}$ of methanolic DPPH solution. Replacing the extract with 100\% methanol solution the control reaction was made. The mixture was incubated for $30 \mathrm{~min}$ in dark at ambient temperature and thereafter the absorbance was measured at $517 \mathrm{~nm}$ UV-Visible spectrophotometer [10]. The Antioxidant activity was calculated using the following equation:

$\%$ DPPH Scavenging activity $=100 \times \frac{\mathrm{Abs}_{\text {Control }}-\mathrm{Abs}_{\text {Sample }}}{\mathrm{Abs}_{\text {Control }}}$

\section{Total phenolic content}

The total phenolic content of A.pavonina was determined spectrophotometrically using Folin-Ciocalteu's reagent. The extract $(100 \mu \mathrm{l} ; 1 \mathrm{mg} / \mathrm{ml})$ was mixed with $100 \mu \mathrm{l}$ of Folin-Ciocalteu's phenol reagent and kept for 
5 min. A volume of $1.00 \mathrm{ml}$ of a $7 \% \mathrm{Na}_{2} \mathrm{CO}_{3}$ solution was added to the reaction mixture followed by addition of $1.30 \mathrm{ml}$ of deionized (DI) water. The mixture was kept in the dark at ambient temperature for $90 \mathrm{~min}$ and thereafter the absorbance measured at $750 \mathrm{~nm}$. A calibration graph was prepared using Gallic acid as the standard and the total phenolic content in the extract was expressed as milligrams of Gallic acid equivalents in one gram of extract $[10,11]$.

\section{Brine shrimp cytotoxicity bioassay}

The plant extract was dissolved initially in $100 \mu \mathrm{l}$ of DMSO and was further dissolved in artificial sea water to give concentrations ranging from 125 to $1000 \mu \mathrm{g} / \mathrm{ml}$. Artificial sea water was prepared using the Cold Spring Harbor Laboratory protocol, 2011 [12]. A $26.29 \mathrm{~g}$ of $\mathrm{NaCl}(450 \mathrm{mM})$, 0.74 g KCl (10 mM), $\mathrm{CaCl}_{2} 0.99 \mathrm{~g}(9 \mathrm{mM}), \mathrm{MgCl}_{2} \cdot 6 \mathrm{H}_{2} \mathrm{O}$ $6.09 \mathrm{~g}(30 \mathrm{mM})$ and $\mathrm{MgSO}_{4} \cdot 7 \mathrm{H}_{2} \mathrm{O} 3.94 \mathrm{~g}(16 \mathrm{mM})$ was dissolved in $1 \mathrm{~L}$ deionized water and was filtered by using Whatmann filter paper No. 42. The $\mathrm{pH}$ of the solution was adjusted to 7.8 and autoclaved and was store at $4{ }^{\circ} \mathrm{C}$ until use (maximum for 1 week). Two milliliters of the extract solution was added into separate test tubes and ten mature brine shrimps were added into each test tube. The test tubes were incubated at $30{ }^{\circ} \mathrm{C}$ for $24 \mathrm{~h}$ and counted the live shrimp under magnification. The number of deaths of shrimps was plotted against extract concentration and the $\mathrm{LD}_{50}$ value was estimated [13]. Potassium dichromate dissolved in artificial seawater at concentrations ranging from 125 to $1000 \mu \mathrm{g} / \mathrm{ml}$ was used as positive controls of the experiment. Each experiment was performed in was performed in triplicates.

\section{Results}

\section{In vitro a-amylase inhibitory studies}

Evaluating the plot of $\% \alpha$-amylase inhibition as a function of extract concentrations (Fig. 1), the $\mathrm{IC}_{50}$ values were calculated (Table 1). The crude $\mathrm{MeOH}$ extract exhibited the lowest $\mathrm{IC}_{50}$ of $16.16 \pm 2.23 \mu \mathrm{g} / \mathrm{ml}$ and the $\mathrm{IC}_{50}$ values of EtOAc, petroleum ether, and the water extracts were $59.93 \pm 0.25,145.49 \pm 4.86$ and $214.85 \pm$ $9.72 \mu \mathrm{g} / \mathrm{mL}$ respectively. The standard positive control Acarbose showed an $\mathrm{IC}_{50}$ of $18.63 \pm 1.21 \mu \mathrm{g} / \mathrm{ml}$. In this study, significant differences were found between the $\mathrm{IC}_{50}$ values of all extracts $\left(P=2.23 \times 10^{-11}\right.$, one-way ANOVA). However, the difference between the $\mathrm{IC}_{50}$ of Acarbose and the methanol extract did not show a significant difference ( $P=0.175$, one-way ANOVA).

\section{Antioxidant activity}

\section{Total phenolic content}

The total phenolic content (TPC) is expressed as Gallic acid equivalents in $\mathrm{mg} / \mathrm{g}$ of extract (Table 1, Fig. 2). The crude $\mathrm{MeOH}$ extract of $A$. pavonia contained $9.73 \pm$

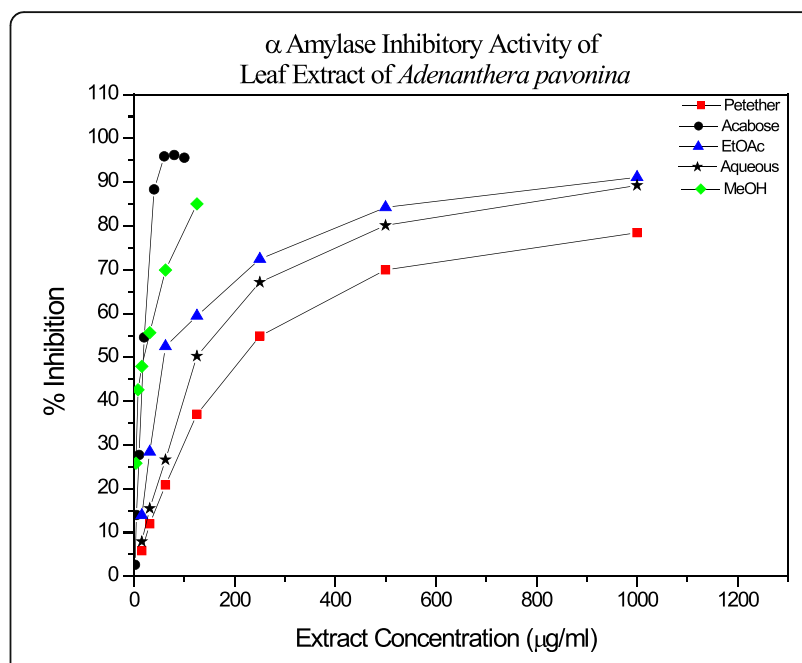

Fig. 1 Enzyme inhibition (\%) as a function of Adenanthera pavonina extract concentration

$0.12 \mathrm{mg}$ Gallic acid equivalents/g of extract and the EtOAc aqueous and the petroleum ether extract showed a phenolic content of $34.62 \pm 1.14,13.46 \pm 0.11$ and $2.88 \pm$ $0.23 \mathrm{mg}$ of Gallic acid equivalents per gram extract respectively.

\section{DPPH radical scavenging activity}

The DPPH radical scavenging activities of the $A$. pavonina extracts showed IC 50 value of $751.66 \pm 4.91$, $423.62 \pm 2.45$ and $249.92 \pm 3.35 \mu \mathrm{g} / \mathrm{ml}$ for the extracts of petroleum ether crude methanol and ethyl acetate respectively (Fig. 3, Table 1). The best activity was observed in the EtOAc fraction with an $\mathrm{IC}_{50}$ value of $249.92 \pm 3.35 \mu \mathrm{g} / \mathrm{ml}$ and $\mathrm{IC}_{50}$ of the aqueous extract was not determined, as it was greater than $1 \mathrm{mg} / \mathrm{ml}$. The $\%$ inhibition of the aqueous extract at $1 \mathrm{mg} / \mathrm{ml}$ was only $25.87 \pm 1.75 \%$. Significant differences were found between the $\mathrm{IC}_{50}$ values of all extracts for the $\mathrm{DPPH}$ scavenging activity ( $P=0.00019$, one-way ANOVA).

\section{Brine shrimp cytotoxicity assay}

$\mathrm{LD}_{50}$ values lower than $1000 \mu \mathrm{g} / \mathrm{ml}$ is considered to be cytotoxic in the toxicity evaluation of plant extracts

Table 1 Total Phenolic Content (as Gallic acid equivalents), I $C_{50}$ $(\mu \mathrm{g} / \mathrm{ml})$ of DPPH scavenging activity and $\mathrm{IC}_{50}(\mu \mathrm{g} / \mathrm{ml})$ of a amylase inhibitory activity of Adenanthera pavonina leaf extracts

\begin{tabular}{lllr}
\hline Extract & $\begin{array}{l}\text { Total Phenolic } \\
\text { Content (Gallic } \\
\text { acid equivalents } \\
\mathrm{mg} / \mathrm{g} \text { extract) }\end{array}$ & $\begin{array}{l}\text { DPPH } \\
\text { Scavenging } \\
\text { Activity } \\
\left(\mathrm{I} \mathrm{C}_{50}(\mu \mathrm{g} / \mathrm{ml})\right.\end{array}$ & $\begin{array}{l}\text { a-amylase } \\
\text { inhibitory } \\
\text { activity } \\
\mid \mathrm{IC}_{50}(\mu \mathrm{g} / \mathrm{ml})\end{array}$ \\
\hline Crude Methanol & $9.73 \pm 0.12$ & $423.62 \pm 2.45$ & $16.16 \pm 2.23$ \\
Ethyl Acetate & $34.62 \pm 1.14$ & $249.92 \pm 3.35$ & $59.93 \pm 0.25$ \\
Petroleum Ether & $13.46 \pm 0.11$ & $751.66 \pm 4.91$ & $145.49 \pm 4.86$ \\
Aqueous & $2.88 \pm 0.23$ & $>1000$ & $214.85 \pm 9.72$ \\
\hline
\end{tabular}




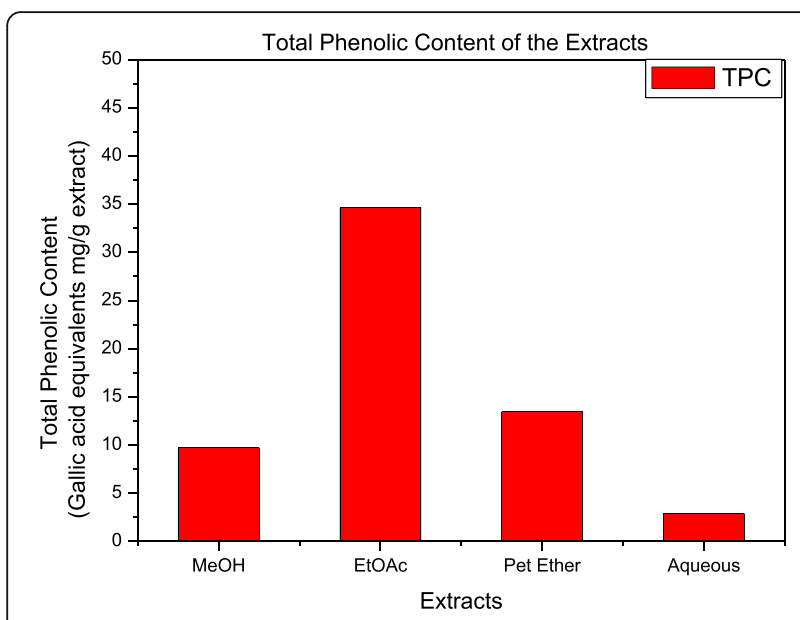

Fig. 2 Total phenolic content as Gallic acid equivalents in extracts of Adenanthera pavonina extracts

using brine shrimp assay [13]. The $\mathrm{LD}_{50}$ value of the crude methanol extract of $A$. pavonina leaves was estimated to be $1963.936 \mu \mathrm{g} / \mathrm{ml}$ indicating the absence of cytotoxic compounds in the extract.

\section{Discussion}

The trend in the screening of medicinal plants for antidiabetic activity has increased, as it is important to discover novel effective drugs for the disease. However, the WHO has recommended daily exercise and healthy food intake as an effective method of controlling the diabetes type II [1]. Therefore promoting the urban population for a healthy living style with the use of greens that possess anti-diabetic activity and antioxidant activity in their daily diet would be one of the cost-effective ways of controlling the disease. Though seed and leaf extracts have exhibited hypoglycemic and antihyperglycemic activity

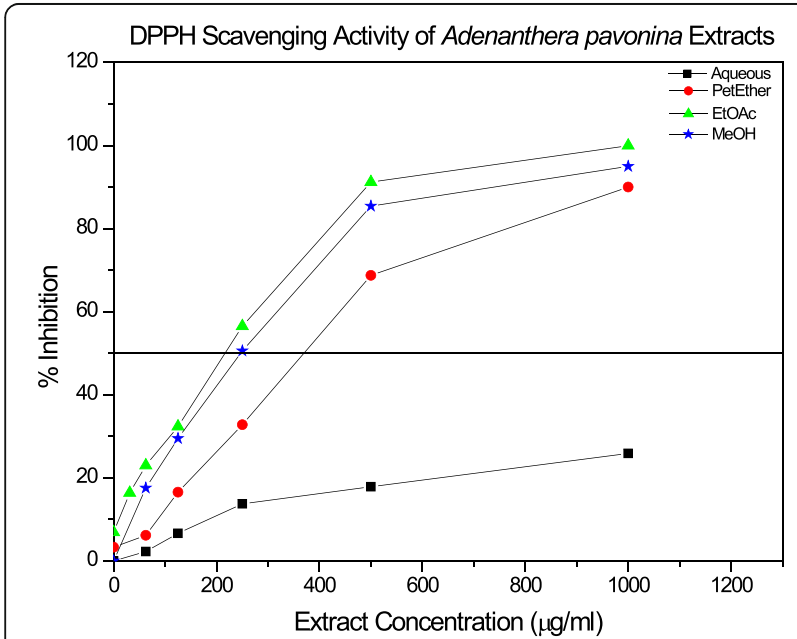

Fig. 3 The plot of DPPH radical scavenging activity as a function of Adenanthera pavonina extract concentrations as tested on rat models this study would be the first report on detailed $\alpha$ - amylase inhibitory activity study to the best of our knowledge.

The $\alpha$-amylase inhibitory studies performed demonstrated that the extracts of A.pavonina (crude $\mathrm{MeOH}$, EtOAc, pet-ether and water) had significant inhibitory potentials. The $\mathrm{IC}_{50}$ value $(16.16 \pm 2.30 \mu \mathrm{g} / \mathrm{ml})$ of methanol extracts is almost similar to that of Acarbose (18.63 \pm $1.21 \mu \mathrm{g} / \mathrm{ml}$ ) a widely used and marketed anti-diabetic drug. These $\alpha$ - amylase inhibitors are also called as starch blockers as they prevent or slows the absorption of starch into the body mainly by blocking the hydrolysis of 1,4-glycosidic linkages of starch and other oligosaccharides into maltose, maltriose and other simple sugars [14]. The $\alpha$ amylase inhibitory activity in methanol extract is most likely to be due to polar compounds and is worth investigating further and isolating pure active compounds.

It is predicted that diabetic complications occur as a result of the oxidative stress due to the formation of free radicals with the glucose oxidation and the subsequent oxidative degradation of glycated proteins [15]. Therefore the use of antioxidants along with anti-diabetic drugs are frequently recommended to avoid such complications. The antioxidant activities measured by DPPH scavenging properties and the total phenolic content of the A. pavonina leaf extracts reveals all extracts does possess mild antioxidant properties with ethyl acetate fraction exhibiting the best DPPH scavenging property ( $\mathrm{IC}_{50}$ of $249.92 \pm 3.35 \mu \mathrm{g} / \mathrm{ml}$ ) and with the highest total phenolic content of $34.62 \pm 1.14$ (Gallic acid equivalents $\mathrm{mg} / \mathrm{g}$ extract). The preliminary investigation carried out on cytotoxicity using brine shrimps show that the methanol leaf extract does not carry toxic compounds as the $\mathrm{LD}_{50}$ value was higher than $1 \mathrm{mg} / \mathrm{ml}$ $(1963.936 \mu \mathrm{g} / \mathrm{ml})$.

Hence the above results suggest that the leaf extracts of $A$. pavonina could be greatly beneficial in reducing the absorption of starch into the body also can be effectively used in ayurvedic treatments. Since leaves of $A$. pavonina is used mostly among the rural population as a green vegetable use of this leafy vegetable can be promoted among the urban population for its health benefits especially in the management of diabetics.

\section{Conclusion}

According to the result of the study on the leaf extracts of Adenanthera pavonina exhibit $\alpha$-amylase inhibitory activity with remarkable activity in the crude methanolic extract. Hence leaves of Adenanthera pavonina has the potential to be used as a green vegetable and also be used in ayurvedic decoctions in controlling and treatment of Type II diabetes mellitus. Furthermore, this study has opened opportunities for future research in searching for novel effective drugs for diabetics that possess both antioxidant activity and anti-diabetic activity. 


\section{Acknowledgments}

Not Applicable.

\section{Funding}

University of Peradeniya.

\section{Availability of data and material}

All data generated or analyzed during this study are included this published article.

\section{Authors' contributions}

JCP-Performing all research experiments. MNW-Research Advisor and preparation of the manuscript. DBMW-Research advisor and providing funds for the research. All authors read and approved the final manuscript.

\section{Authors' information}

Ms. J.C. Punchinewa (BSc Pharmacy)

Research Student/Demonstrator at the Department of Pharmacy Faculty of Allied Health Sciences, University of Peradeniya Peradeniya Sri Lanka. chamanipunchihewa2@gmail.com

Dr. M. Nirmali Wickramaratne (Ph.D. Biochemistry)

Senior Lecturer Gr I/Research advisor attached to the Department of Physical Sciences and Technology, Faculty of Applied Sciences, Sabaragamuwa University of Sri Lanka, Belihuloya, Sri Lanka. meritanirmali@gmail.com Prof. D.B.M. Wickramaratne (Ph.D. Medicinal Chemistry and Pharmacognosy) Professor/Research advisor Faculty of Allied Health Sciences University of Peradeniya, Peradeniya, Sri Lanka. deanahs@pdn.ac.lk

\section{Competing interests}

The authors declare that they have no competing interests. Non-financial competing interests include (but are not limited to) political, personal, religious, ideological, academic, and intellectual competing interests.

\section{Consent for publication}

Not Applicable.

\section{Ethics approval and consent to participate}

Not Applicable.

\section{Author details}

'Department of Physical Sciences and Technology, Faculty of Applied Sciences, Sabaragamuwa University of Sri Lanka, Belihuloya, Sri Lanka. ${ }^{2}$ Department of Pharmacy Faculty of Allied Health Sciences, University of Peradeniya, Peradeniya, Sri Lanka. ${ }^{3}$ Faculty of Allied Health Sciences, University of Peradeniya, Peradeniya, Sri Lanka.

Received: 25 July 2016 Accepted: 9 November 2016

\section{Published online: 15 November 2016}

\section{References}

1. WHO Fact Sheet Fact sheet. 2015. №312 http://www.who.int/mediacentre/ factsheets/fs312. Accessed 24 Jan 2016.

2. The American Diabetes Association. Diagnosis and classification of diabetes mellitus. Diabetes Care. 2012;35(1):64-71.

3. Ab Hamid MR, Mustafa Z, Suradi NRM, Idris F, Abdullah M. Multi-factor of employee values: A confirmatory factor analytics (CFA) validation. Afr J Business Management. 2010;5(32):12632-40.

4. Roberts LJ, Oates JA, Linton MF, Fazio S, Meador BP, Gross MD, Shyr Y, Morrow JD. The relationship between dose of vitamin $\mathrm{E}$ and suppression of oxidative stress in humans. Free Radic Biol Med. 2007;10:1388-93.

5. Pandhare RB, Sangameswaran B, Mohite PB, Khanage SG. Attenuating effect of seeds of Adenanthera pavonina aqueous extract in neuropathic pain in streptozotocin-induced diabetic rats: an evidence of neuroprotective effects. Braz J Pharmacognosy. 2011;22(2):428-35.

6. Arzumand ARA, Hashem MDA, Muslim T. Chemical investigation of the bark of the Adenenthera Pavonona Linn. Int J Chem Sci. 2012;10(1):98-103.

7. Dissanayake DMRK, Wijayabandara MDJ, Ratnasooriya WD. Hypoglycemic and Antihyperglycaemic Activities of an Aqueous Leaf Extract of Adenanthera Pavonina (Fabaceae) in Rats. Int J Pharm Res \& Allied Sci. 2016;5(1):34-8.

8. Miller GL. Use of dinitrosalicylic acid reagent for determination of reducing sugar. Anal Chem. 1959;31:426-8.
9. Gulluce M, Sahin F, Sokmen M, Ozer H, Daferera D, Sokmen A, Polissiou M, Adiguzel A, Ozkan H. Antimicrobial and antioxidant properties of the essential oils and methanol extract from Mentha longifolia L. ssp. longifolia. Food Chem. 2007:103:1449-56.

10. Wickramaratne MN, Gunatilake LP, Anuradha NGD, Godavillathanna AN, Perera MGN, Nicholas I. Antioxidant Activity and Antibacterial Activity of Walidda antidysenterica. J Pharmacog and Phytochem. 2015;4(2):121-6.

11. Stankovic MS. Total phenolic content, flavonoid concentration and antioxidant activity of Marrubium peregrinum L. extracts. Kragujevac J Sci. 2011;33:63-72.

12. Cold Spring Harb Protoc. 2012; doi:10.1101/pdb.rec068270, @ Cold Spring Harbor Laboratory Press.

13. Meyer BN, Ferrigni NR, Putnam JE, Jacobson LB, Nichols DE, McLaughlin JL. Brine shrimp: a convenient general bioassay for active plant constituents. Planta Med. 1982:45:31-4.

14. Kumar BD, Mitra A, Manjunatha M. A comparative study of alpha-amylase inhibitory activities of common antidiabetic plants of Kharagpur 1 block. Int J Green Pharm. 2010:4:115-21.

15. Mehta JL, Rasouli N, Sinha AK, Molavi B. Oxidative stress in diabetes: a mechanistic overview of its effects on atherogenesis and myocardial dysfunction. Int J Biochem Cell Biol. 2006;38:794-803.

\section{Submit your next manuscript to BioMed Central and we will help you at every step:}

- We accept pre-submission inquiries

- Our selector tool helps you to find the most relevant journal

- We provide round the clock customer support

- Convenient online submission

- Thorough peer review

- Inclusion in PubMed and all major indexing services

- Maximum visibility for your research

Submit your manuscript at www.biomedcentral.com/submit
) Biomed Central 